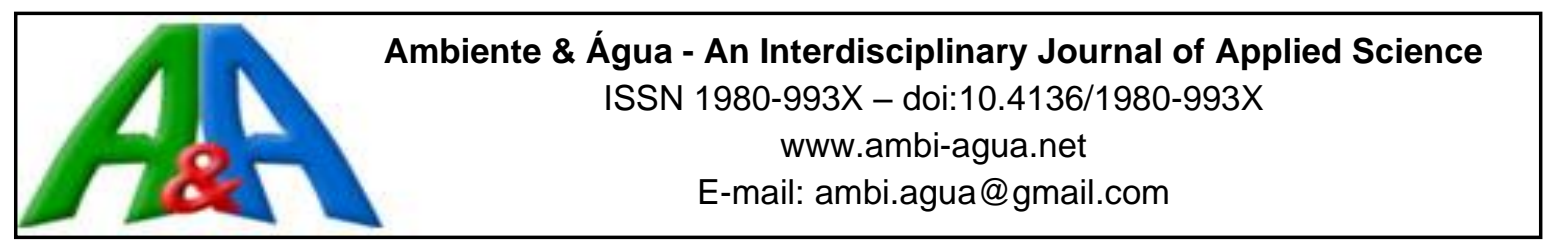

\title{
Composition and floral diversity in Andean grasslands in natural post-harvest restoration with Lepidium meyenii Walpers
}

\author{
ARTICLES doi:10.4136/ambi-agua.2351
}

Received: 27 Nov. 2018; Accepted: 07 Aug. 2019

\author{
Raúl Yaranga $^{1^{*}(\mathbb{D})}$; María Custodio ${ }^{1}$; ; Edith Orellana ${ }^{1}$ \\ ${ }^{1}$ Centro de Investigación en Alta Montaña (CIAM), Facultad de Zootecnia, Universidad Nacional del Centro del \\ Perú (UNCP), Avenida Mariscal Castilla, n³ 3909, CEP 12006, Huancayo, Peru. \\ E-mail: mcustodio@uncp.edu.pe,edithorellana5@yahoo.es \\ *Corresponding author. E-mail: yarangacano@gmail.com
}

\begin{abstract}
The Andean grassland ecosystems undergo natural and anthropogenic degradation processes. The change of land use for agricultural use is the greatest threat, with a great loss of biodiversity followed by a very slow process of revegetalization. The objective was to assess the richness, abundance and diversity, alpha and beta, in areas of two-, three-, five-, six- and eight years of post-harvest abandonment of Lepidium meyenni Walpers. Ten affected areas were selected for agrostological evaluation, through four linear transects of interception points with 100 records each, applied on the edge and inside the affected area, inside and outside the affected areas, as well as samples composed of soils for each area. Composite soil samples were collected from each transect and study area to analyze their physical and chemical properties. The data were analyzed using the generalized linear mixed model with Rstudio v 5.3.2, and the multivariate analysis of canonical correspondence between biological and environmental variables, using CANOCO v.1.4 software. A significant difference was found between floral composition and alpha diversity according to abandonment time and seasonal periods. The greatest richness and abundance was observed between five- and eight years of abandonment, due to the greater presence of perennial species. Linear correspondence of alpha richness and diversity with organic matter, nitrogen, soil phosphorus and abandonment time was observed.
\end{abstract}

Keywords: alpha diversity, Andean grassland, beta diversity, dominance richness.

\section{Composição e diversidade florística em campos andinos em restauração pós-colheita natural com Lepidium meyenii Walpers}

\section{RESUMO}

Os ecossistemas de prados andinos sofrem processos de degradação natural e antropogênica. A mudança de uso da terra para uso agrícola é a maior ameaça com grande perda de biodiversidade, seguido por um processo muito lento de revegetação. O objetivo do estudo foi avaliar a riqueza, abundância e diversidade alfa e beta em áreas de dois, três, cinco, seis e oito anos pós-colheita Lepidium meyenni Walpers. Foram estabelecidas dez áreas afetadas para avaliação agrostológica por meio de quatro transectos lineares de pontos de interceptação com 100 registros aplicados na borda e no interior da área afetada. Amostras compostas de solo foram coletadas de cada transecto e da área de estudo para analisar suas propriedades físicas e químicas. Os dados foram analisados por meio do modelo linear generalizado misturado com 
Rstudio v 5.3.2 e da análise multivariada de correspondência canônica entre variáveis biológicas e ambientais, utilizando o software CANOCO v.1.4. Uma diferença significativa foi encontrada entre composição florística e diversidade alfa de acordo com o tempo de abandono e períodos sazonais. A maior riqueza e abundância foi observada entre cinco e oito anos de abandono, devido à maior presença de espécies perenes. Observou-se correspondência linear de riqueza e diversidade alfa com matéria orgânica, azoto, fósforo do solo e tempo de abandono.

Palavras-chave: diversidade alfa, diversidade beta, pastagem Andina, riqueza florística e dominância.

\section{INTRODUCTION}

Natural grassland ecosystems include a diversity of plant species and provide habitat for diverse wildlife species, as well as important resources for humanity and the environment (Rolando et al., 2017). The floral diversity of the grassland ecosystems of these high Andean ecoregions (Britto, 2017) is similar in complexity and heterogeneity to the patterns of floral variation determined by gradients (Cuesta and Becerra, 2012). Species richness generally declines as elevation increases (McCain and Grytnes, 2010). Whittaker (1960) demonstrated a positive relationship between temperature and precipitation and species richness for many diversity patterns (Hawkins et al., 2003) and as the study area increases, the number of species found increases (Rosenzweig, 1995). On the other hand, the history of agricultural-livestock use (Mudongo et al., 2016) and the feeding ofanimal by grazing (Yaranga et al., 2018), the strategy of grasslands' adaptation to climate change and the economic factors of the herders (Hinojosa et al., 2016) determine the diversity of species.

These ecosystems are being severely disturbed in their structure and function by the change of pasture land use for agricultural purposes, with a great loss of biodiversity and the generation of a secondary succession process (Schmidt, 2018). Revegetation begins with the establishment of pioneering invasive species unrelated to the original composition (Wiesmair et al., 2017), generating important changes in physiognomic and physiological properties (Gartzia et al., 2016; Silva Mota et al., 2018) and causing the decrease of multiple environmental services according to the variation of spatiotemporal scenarios (Tang et al., 2018). In different parts of the world faced with these problems, strategies have been developed to reverse these processes through conservation and restoration (Jurado et al., 2013; Caro et al., 2014).

In the central Andes of Peru, the change in the use of Andean grasslands through the cultivation of Lepidium meyenii Walpers, due to the removal of the soil with loss of vegetation cover, constitutes the greatest regional concern. This is due to the fact that the recovery of plant communities is slow during the four years of rest, and their capacity to shelter diverse species is diminished (Cao et al., 2017), and they are gradually being repopulated by herbaceous communities very different from the original ecosystem, substituting the original plant community for another (Cárdenas, 2013).

The quantification of species richness, abundance and similarity through alpha and beta diversity indices allows studying changes in the plant community. For this, it is important to identify the species with the highest importance (Silva Mota et al., 2018) based on the relative abundance and community structure of species (Moreno, 2001; Moreno et al., 2011; Barragán Solís et al., 2011), since these determine the characteristics of the plant community and the function of the ecosystem according to environmental gradient and limiting factors referred to by Whittaker and Clements (Hagen, 2012), in addition to being an indication of the level of relevance among the other species and the level of spatial occupation (Enriquez et al., 2016). Alpha diversity, also known as specific diversity, varies in time from one site to another, in relation to the spatial and temporal gradient between communities or habitats (Halffter et al., 2005), and is used in the ecological evaluation of conservation and restoration of ecosystems 
(Caballero-Vázquez and Vega-Cendejas, 2012). Beta diversity, on the other hand, implies knowing the degree of replacement of species between communities or the number of species that share two or more communities (Moreno, 2001).

This study assessed the richness, abundance and floral diversity of vascular plants in Andean grassland areas with land-use change, in space-time gradients of two-, three-, five-, sixand eight years of post-harvest abandonment of Lepidium meyenii Walpers and two seasonal periods.

\section{MATERIAL AND METHODS}

\subsection{Study area}

The study was conducted in "Lomo Largo", in the district of Pomacancha, province of Jauja and department of Junín, between coordinates $11^{\circ} 333^{\prime} 37.50^{\prime \prime}$ and $11^{\circ} 32^{\prime} 02.35^{\prime \prime}$ and between altitudes 3998 and 4262 meters (Figure 1). The study area is covered with natural grass vegetation, mostly poaceae and asteraceae, with a scarce presence of shrubs such as Margiricarpus pinnatus and Chuquiraga spinosa, which are generally observed in rocky areas and rocky outcrops. The soils are of colluvial origin with parental material formed mainly by rocks: sandstones, shales, slates and quartzite; of very variable depth between 10 and $30 \mathrm{~cm}$, and generally poor in nutrients. The soil is classified as "entisol" according to the "Soil Taxonomy" of the USA, containing less than 30\% of rock fragments (USDA, 2018). However, due to the high physiographic heterogeneity, other soils such as inceptisols and mollisols are observed, due to the altitude of over 3800 meters, cold temperatures, grass cover, and slopes differentiated between $2 \%$ and $15 \%$.

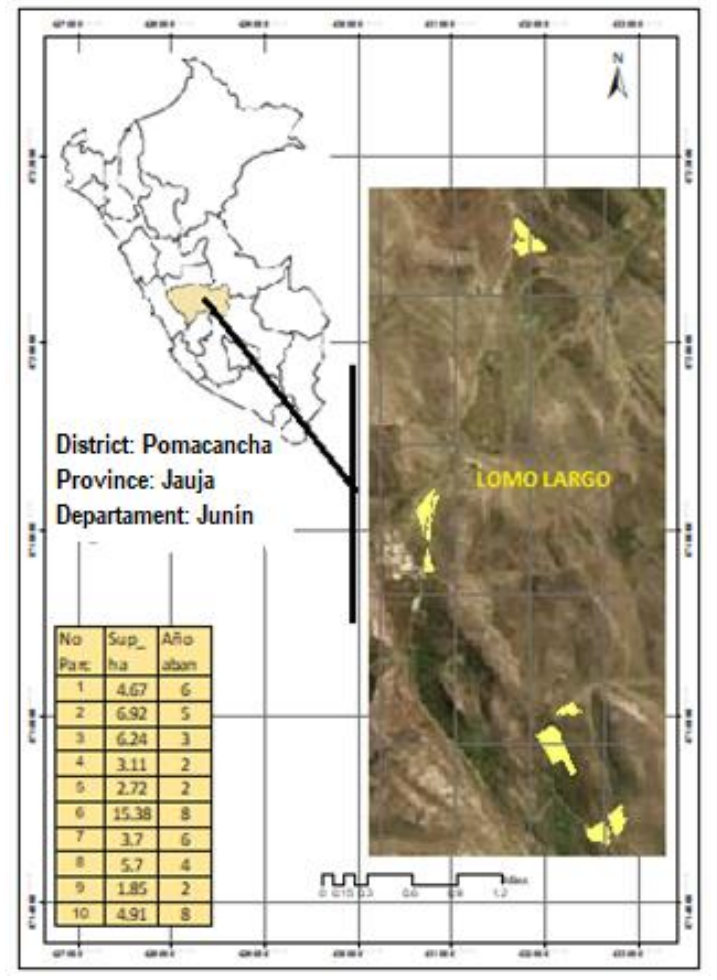

Figure 1. Location map of the study. Área 1 starts on the north side.

The rainy season occurs from October to April, with a peak of greater precipitation between January and March, with accumulated precipitation between 106 and $118 \mathrm{~mm}$ per month. The dry season occurs from May to September with minimum precipitation of 8.9 to 28 
$\mathrm{mm}$ per month. The average maximum daytime temperature fluctuates between 12.87 and $14.63^{\circ} \mathrm{C}$, the minimum nighttime and early morning temperature fluctuates between 0.8 and $5.4^{\circ} \mathrm{C}$, according to data obtained from the Ricran Meteorological Station.

\subsection{Methods}

\subsubsection{Agrostological evaluation and soils}

Ten areas affected by land-use change were identified and established with two-, three-, five-, six- and eight years of post-harvest abandonment with L. meyenii, based on cultivation history provided by the ranchers at the study site. The agrostological evaluation was carried out using the "point interception line" method proposed by the Gloria Method (Enriquez et al., 2016), which consisted of reading 100 points at intervals of $10 \mathrm{~cm}$, in which the following were recorded: vascular plant species, mulch, moss, eroded soil and rock. In each affected area, four transects on the outer edge (native vegetation) and four transects inside the affected area (revegetation) were carried out in May (rainy season) and August (dry season) in 2017, according to the protocol of the GLORIA methodology (Cuesta and Becerra, 2012), used by the Network to monitor the impacts of climate change on biodiversity in the countries of the Andean region (Halloy, 2011). Species recognition was carried out by experts from the Faculty of Zootechnics and the Faculty of Forestry and Environmental Sciences (depository of the constructed herbarium) of the National University of Central Peru, authorized by Resolution No. 095-2018-MINAGRI-SERFOR/DGGSPFF of the Forestry and Wildlife Service.

Soil sampling was carried out according to the technique recommended by the Ministry of the Environment [MINAM] (Perú, 2014) at a depth of $30 \mathrm{~cm}$. Three soil samples were collected per transect, which were mixed to obtain a sample composed of native vegetation and another from the revegetation area, which were sent to the soil laboratory of the National Agricultural Research Institute (INIA) Santa Ana de Huancayo, for the analysis of soil texture, $\mathrm{pH}$, organic matter $(\mathrm{OM})$, nitrogen $(\mathrm{N})$, phosphorus $(\mathrm{P})$ and potassium $(\mathrm{K})$.

\subsubsection{Data analysis}

The data obtained in the field and laboratory were systematized in a double entry matrix in Excel sheet, adopting the method of the species list presentation used by Uchida et al. (2018) for each area, separated between native vegetation and revegetalization area. The agrostological sampling quality test was performed using the cumulative curve method recommended by Kindt and Coe (2011). The floral data was transformed into abundance using the formula: number of individuals of the species divided by the total number of individuals recorded for each transect. The procedure performed by Ali et al. (2017) in the Significant Minimum Difference (LSD) comparison test was adopted to separate the different means $(p \leq 0.05)$ using the generalized mixed linear model, with the use of RStudio software version 3.5.2. in the analysis of richness and abundance, Shannon Wiener alpha diversity index ( $\left.\mathrm{H}^{\prime}\right)$, and Jaccard (Ij) beta diversity index (Moreno, 2001). Multivariate analysis was also carried out between biological variables and environmental variables (revegetation time, seasonal period and soil characteristics) as explanatory variables, by means of the canonical correspondence analysis (CCA) that allows for visualization in a geometric figure, the proximities between the set of biological data with certain predictor variables (Cayuela, 2011) in a final biplot graph (Montanero, 2018), using CANOCO software version 4.5.

\section{RESULTS AND DISCUSSION}

\subsection{Richness and abundance}

In the native vegetation around the affected areas, 24 families with 57 genera and 79 
species were found, of which the family Poaceae contributes with 28 species, the family Asteraceae with 16 species, followed by Fabaceae with four species. In the areas in post-harvest revegetation of $L$. meyenii, abandoned after the only harvest of the product, 23 families with 55 genera and 73 species were found, including 23 species of the family Poaceae and 16 species of the family Asteraceae. The composition of genera and species in both vegetations varied according to seasonal periods and post-harvest abandonment time. The greatest importance of the Poaceae family is a fundamental characteristic of natural grass ecosystems of any environmental condition in the world (Fiallos et al., 2015); it diminishes or loses its composition due to anthropogenic intervention, and does not show a complete recovery, despite several years of revegetation (Sedlar et al., 2017). Significant differences were observed in the number and abundance of species between seasonal periods, mainly in revegetation areas. Richness varied according to seasonal periods and post-harvest abandonment time with L. meyenii.

The small variation in the number of families could be due to the environmental conditions of location within the humid Subalpine Tropical paramo life zone, where the 10 evaluated areas are located. However, the variation in the number of genera and species was significant after five years of post-harvest abandonment, due to the rugged microclimatic condition of the soil and the scarcity of rainfall (Uchida et al., 2018). The composition and floristic structure continued until the age of 15 , since the process of revegetation in the areas affected by land-use change follows a sequential pattern, first entering temporary species with great capacity to adapt to hostile environmental situations, by the existence of free spaces that allow them to take direct advantage of solar radiation, mainly the infrared that enhances their photosynthetic capacity (Silva Mota et al., 2018), then they are gradually replaced by perennial species more tolerant to competition for light and space. This information is valid for decision making in research processes and the planning of directed restoration actions in grassland ecosystems.

The variation of the richness in the areas of revegetalization according to seasonal period was significant, with $\mathrm{p}=0.001$ and at post-harvest abandonment time level with $L$. meyenii. The areas of five-, six- and eight years were superior to the first years with $p=0.01$, according to the ANOVA analysis using the generalized mixed linear model (Figure 2), the most common species in years two and three post-harvest with $L$. meyenii were: Paspalum pygmaeum Hack, Alchemilla pinnata Ruiz \& Pav, Bidens andícola Kunt and Oxalis sp, while from the age of five they were: $P$. pilgerianum Hack, A. pinnata, Calamagrostis heterophylla Wedd, Stipa depauperata, $B$. andícola.
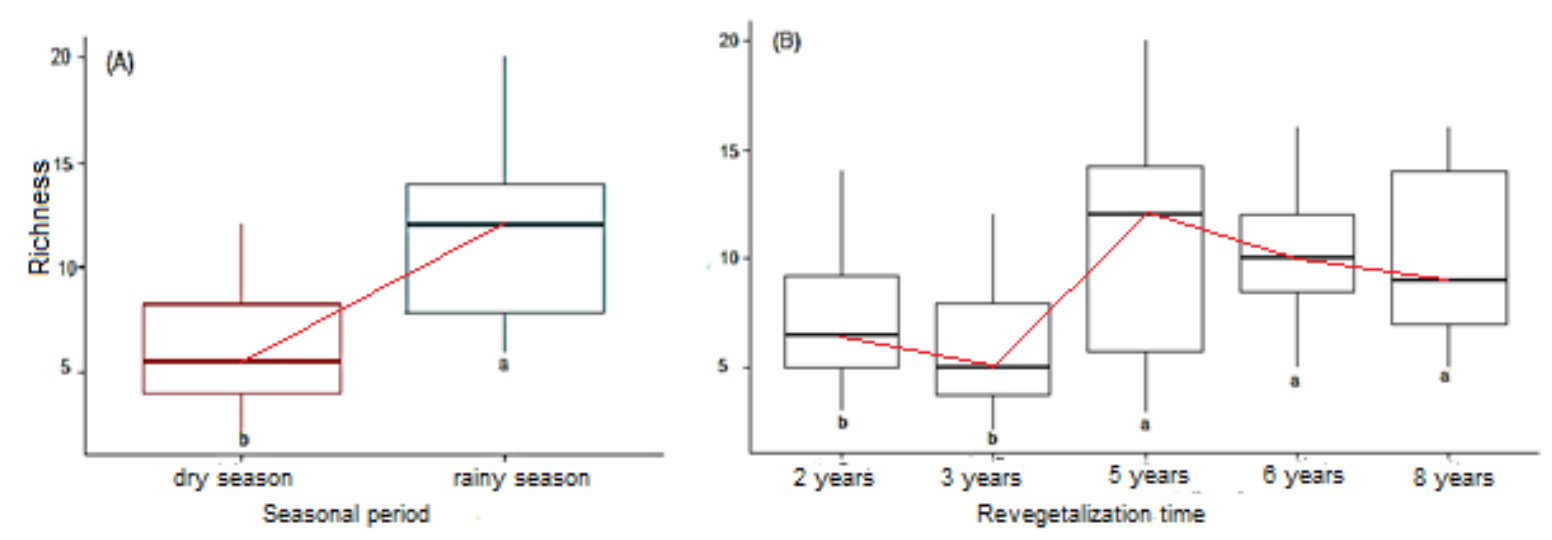

Figure 2. variation of the richness in plots in revegetalization, according to (A) seasonal period and (B) postharvest time of L. meyeni.

The abundance in revegetation plots also varied significantly between seasonal periods with $\mathrm{p}=0.0001$, while at the post-harvest time level no significant difference was found (Figure 3). The 10 species that showed the greatest abundance were: $P$. pilgerianum, $P$. pygmaeum, 
Trifolium amabili Lojac, A. pinnata, Oxalis andicolae Knut, sp, Calamagrostis heterophylla, Paronychia sp, Rumex asetocella, S. depauperata Pilg and B. andícola; of which Alchemilla, Calamagrostis and Stipa are perennial plants, which make a notable presence in the fifth year so that the peak of the curve is also observed.
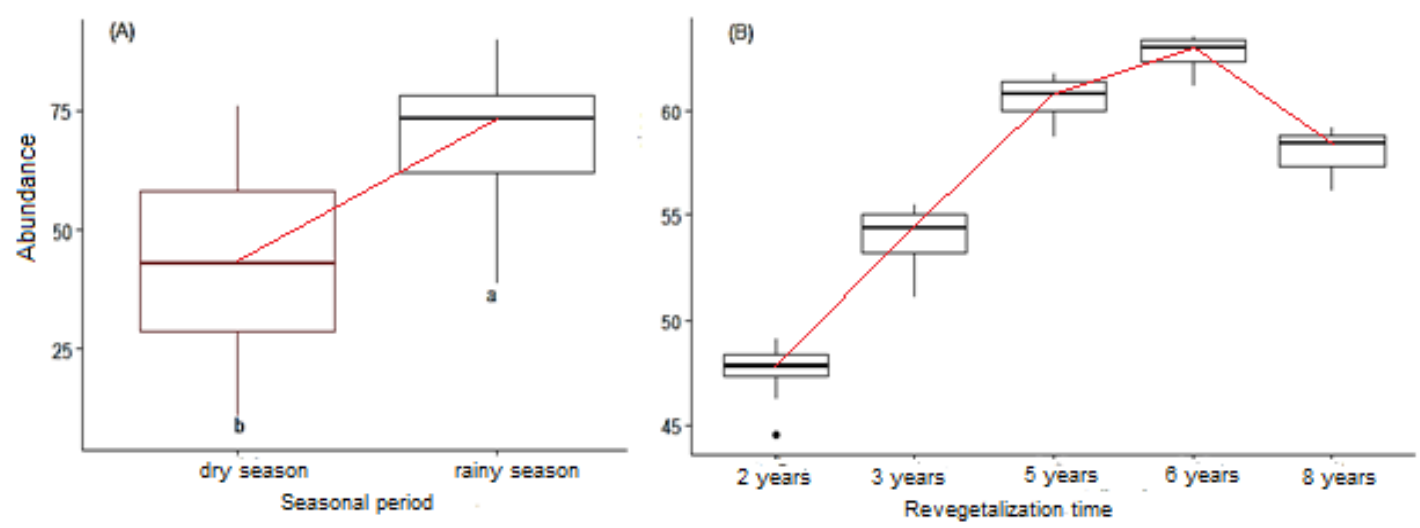

Figure 3. Upper limit of means of abundance, in areas in revegetation according to (A) seasonal period and (B) time of post-harvest abandonment of L. meyenii.

The richness and scarce abundance in the first post-harvest years with $L$. meyenii leaves soils with very little cover, affecting soil conditions mainly by loss of organic matter and nutrients (Mirazadi et al., 2017). The perennial species found in this study are similar to those found in Puno by Cutimbo et al. (2016), and the decrease in species coincides with the results in fragmented areas of Condori (2012), which reaffirms that the floral composition in high mountain ecosystems is somewhat similar.

\subsection{Floristic diversity}

\subsubsection{Alpha Diversity Index}

The relationship between the number of species and their abundance expressed by $\mathrm{H}^{\prime}$ in native vegetation (Table 1) ranged from 2.6 to 3.0 in the seasonal rainy season and from 1.95 to 2.4 in the dry season. In the revegetation areas, it ranged from 2.37 to 2.89 in the rainy season and 1.35 to 2.46 in the dry season. According to the classification range of the index, these values correspond to mean diversity in native vegetation and low diversity in areas with revegetation (Campo and Duval, 2014; Uchida et al., 2018).

Table 1. Alpha diversity indices according to years of abandonment in two seasonal periods.

\begin{tabular}{lccccc}
\hline Transects & 2 years & 3 years & 5 years & 6 years & 8 years \\
\hline VN - rainy season & 2.655 & 2.638 & 2.771 & 2.787 & 3.057 \\
VN - dry season & 2.212 & 2.015 & 1.947 & 2.356 & 2.111 \\
PR - rainy season & 2.374 & 2.538 & 2.893 & 2.811 & 2.886 \\
PR - dry season & 1.713 & 1.353 & 2.37 & 2.449 & 2.461 \\
\hline
\end{tabular}

Legend: 2 years $\ldots 8$ years $=$ years of post-harvest abandonment; $\mathrm{VN}=$ native vegetation, $\mathrm{PR}=$ areas in revegetalization.

A significant variation of the $\mathrm{H}^{\prime}$ index was observed between seasonal periods with higher value in the rainy period with $\mathrm{p}=0.00003$. Also a significant increase of the index was observed according to the increase of the post-harvest abandonment time, with more than five-, six- and eight years with $\mathrm{p}=0.001$ (Figure 4), as opposed to the times of two- and three years. This 
indicates that pasture land use change has affected floral diversity for at least five years, and by the relationship between biodiversity and environmental services, particularly the production of useful fodder for livestock (Wehn et al., 2018) which is the economic base of the rural population (Plieninger and Huntsinger, 2018). This behavior of the $\mathrm{H}^{\prime}$ index over time makes it clear that it is important to know the change in species composition over the time of revegetalization in order to understand the effect of anthropogenic action on land-use change in grassland ecosystems (Uchida et al., 2018).
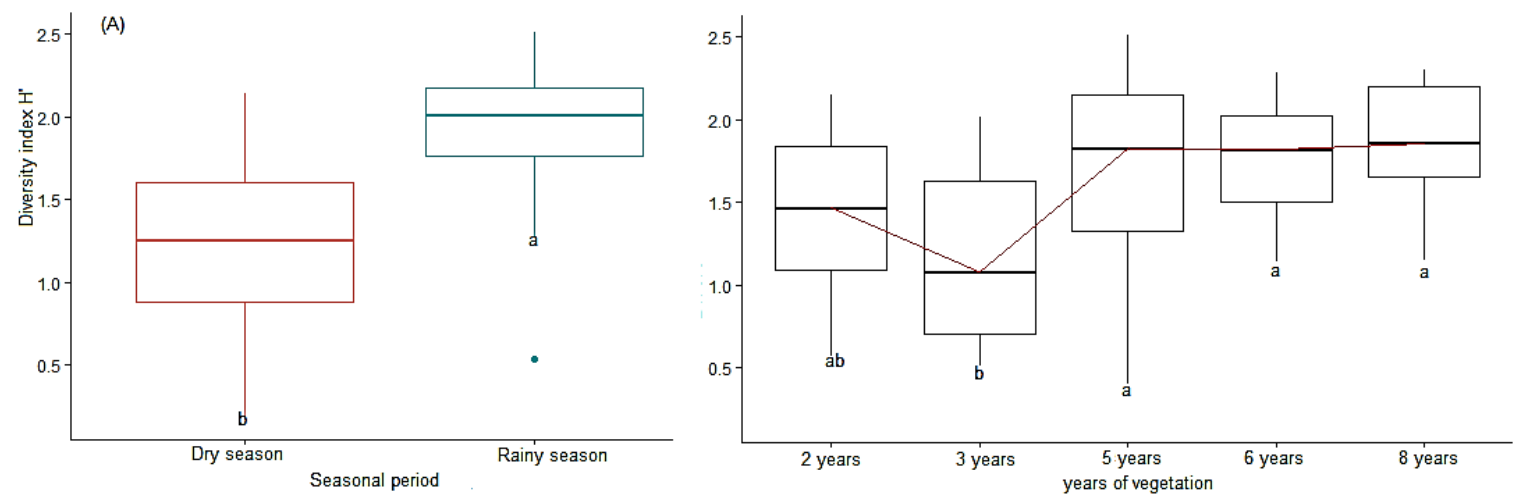

Figure 4. Upper limit of means of diversity of Shannon Wiener and in plots in revegetation according to seasonal period and time of post-harvest abandonment of L. meyenii

Several results have been obtained on alpha diversity indices, for the case of $\mathrm{H}^{\prime}$ they vary between 2.4 and 3.36 in Mexico (Álvarez-Lopeztello et al., 2016), 2.56 in Colombia (GonzálezPinto, 2017), 2.7 to 3.47 in the páramos of Ecuador (Fiallos et al., 2015), in the central Andes of Peru between 2.75 and 3.41 (Yaranga et al., 2018). These values coincide in the classification of medium to low diversity in high mountain pasture conditions, despite its different geographical location on the planet

\subsubsection{Beta diversity index}

The similarity in the presence of species between pairs of areas in times of abandonment was measured by the Jaccard Index (Table 2), the areas with different post-harvest abandonment times of two-, three-, five-, six- and eight years, compared by pairs, in native vegetation share a greater number of species (12 to 18) in the rainy season than in the dry season (9 to 18); in both cases the degree of similarity is intermediate, with values from 0.31 to 0.5 . The areas in revegetation share between 7 to 14 species in the rainy season and 3 to 8 species in the dry season; the degree of similarity varied from intermediate to low. The indices obtained in two-, three- and five- years of post-harvest abandonment showed intermediate levels around 0.5, while in the sixth and eighth years the degree of similarity was low, with values ranging from 0.31 to 0.37 in the rainy season and from 0.29 to 0.46 in the dry season. These results indicated that native vegetation shares between $50 \%$ and $38.2 \%$ of common species in the seasonal rainy period and between $43.8 \%$ and $31 \%$ in low water; while in areas with revegetation they share between $61.3 \%$ and $38.7 \%$ of species in the rainy period between $61.5 \%$ and $29.7 \%$ in the lowwater period.

Beta diversity is a very important ecological indicator that allows us to know the dynamics of the pattern of shared species between areas in recovery according to the years of abandonment, and this is very variable according to the environmental conditions of each place (Condori, 2012; Zhou et al., 2014; Mota et al., 2018). Differences were observed between sampling sites in native vegetation. It is useful to interpret the dynamics of dissimilarity in areas affected by land-use change. The Jaccard index, which measures the capacity to share common species by areas in revegetation, showed higher values than native vegetation, especially in the 
first years of revegetation, which was due to the entry of exotic or invasive species adapted to disturbance conditions in the soil (Sedlar et al., 2017), which decreased as the years of postharvest recovery increased, due to the entry of perennial species that replaced the pioneer species. This influenced the observed medium- to low similarity (Uchida et al., 2018). The value of $J=0.79$ shown by González-Pinto (2017) is high, compared to the lower indices found in the study, due to the fact that in arid regions the richness of grassland communities is lower than in humid regions (Enriquez et al., 2016; Uchida et al., 2018).

Table 2. Jaccard similarity index of native vegetation and plots with revegetation, number of common species in parentheses.

\begin{tabular}{lccccc}
\hline Transects & Years of abandonment & 2 years & 3 years & 5 years & 6 years \\
\hline Native vegitation - & 3 & $0.500(16)$ & & & \\
rainy season & 5 & $0.532(14)$ & $0.511(13)$ & & \\
& 6 & $0.444(18)$ & $0.577(14)$ & $0.382(16)$ & \\
& 8 & $0.418(12)$ & $0.396(12)$ & $0.464(11)$ & $0.429(13)$ \\
\hline Native vegitation - & 3 & $0.438(9)$ & & & \\
dry season & 5 & $0.385(9)$ & $0.375(9)$ & & \\
& 6 & $0.379(18)$ & $0.486(9)$ & $0.310(10)$ & \\
& 8 & $0.375(11)$ & $0.158(11)$ & $0.375(10)$ & $0.371(10)$ \\
\hline & 3 & $0.529(8)$ & & & \\
Revegetation - & 5 & $0.544(7)$ & $0.531(8)$ & & \\
rainy season & 6 & $0.448(10)$ & $0.446(9)$ & $0.408(14)$ & \\
& 8 & $0.613(7)$ & $0.420(9)$ & $0.387(13)$ & $0.474(12)$ \\
\hline & 3 & $0.615(3)$ & & & \\
Revegetation - & 5 & $0.471(5)$ & $0.500(3)$ & & \\
dry season & 6 & $0.421(6)$ & $0.500(4)$ & $0.400(7)$ & \\
& 8 & $0.600(5)$ & $0.379(5)$ & $0.297(8)$ & $0.463(8)$ \\
\hline
\end{tabular}

3.3. Canonical correspondence (CCA) between species dominance and floristic diversity with soil characteristics, according to post-harvest abandonment time, in plots in natural revegetalization

The analysis of the canonical correspondence between the dominance of species in areas in natural revegetation with the physical-chemical characteristics of the soil, the post-harvest abandonment time of L. meyenii, showed the sensitivity among the species of greatest presence in the five-, six- and eight years of post-harvest abandonment of L. meyenii, with organic matter, nitrogen and phosphorus, both in the seasonal rainy period and in the dry season (Figure 5A). The interest of knowing, in simplified way, the relation of the complex set of environmental data that explain the variation of biological indicators (Cayuela, 2011) has taken into account the diversity of grassland ecosystem species as a key component (Fattahi et al., 2017), which varies according to the sensitivity of the species to the variables of the temporal gradient (years of abandonment) and soil factors, which was the interest of our analysis.

This correspondence confirmed the close relationship between soil and vegetation (Fattahi et al., 2017), which, as a result of the increasingly prolonged abandonment time, shows the correspondence of perennial species with organic matter and nitrogen, which are the most important elements in the quality of soils that energize microbial activity (Ali et al., 2017), and 
plant nutrition (Wang et al., 2017), favored by the increase in biomass produced, litterfall, root death and the increase in microorganisms, arthropods and others, which improve soil quality (Acevedo and Delibes-Mateos, 2013; Niemandt and Greve, 2016). This indicated that the postharvest vegetative recovery time is a determining factor in the variation and correspondence of soil characteristics with the richness and abundance of species. This correspondence behavior explained the variability of invasive and temporary species in recently abandoned areas that are not demanding in soil quality (Andrade et al., 2015; Sedlar et al., 2017) and the stability of perennial species in the medium- and long term (Gartzia et al., 2016; Mota et al., 2018).
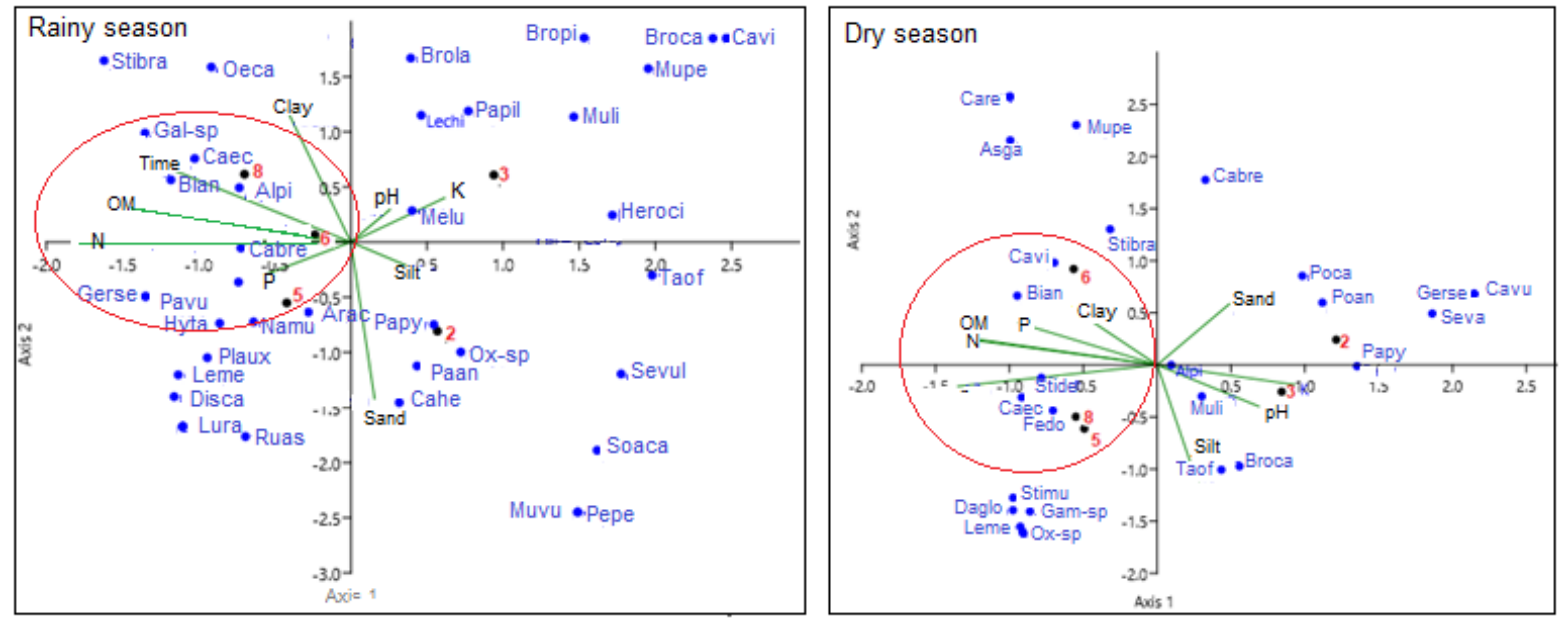

(A) canonical correspondence of the abundance of richness with the physical-chemical characteristics of the soil and the time of abandonment
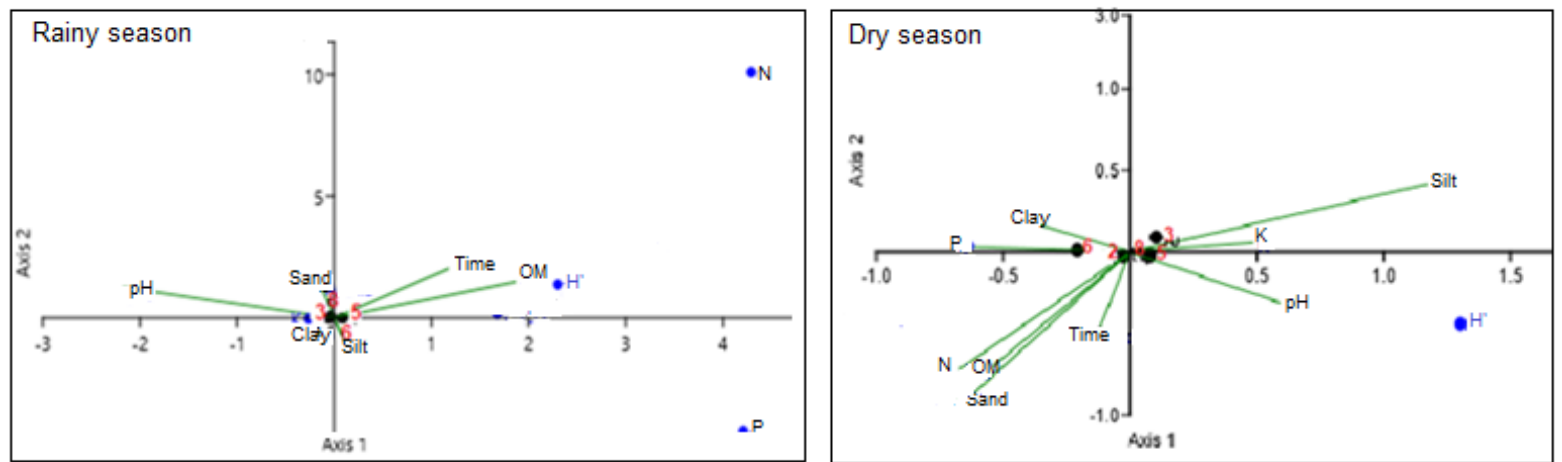

(B) Canonical correspondence of the alpha diversity with the physical-chemical characteristics of the soil and the time of abandonment

Figure 5. Canonical correspondence between A) richness and abundance, B) alpha diversity, in revegetation plots, according to seasonal period and post-harvest abandonment time of L. meyenii.

In the analysis of the canonical correspondence of alpha diversity (Shannon Wiener index - H') with the physical-chemical characteristics of the soil, the post-harvest abandonment time of L. meyenii showed a weak linear relationship of the $\mathrm{H}^{\prime}$ index with the organic matter and the abandonment time in the seasonal rainy period, which was not maintained in the low-water period; on the other hand, the affected areas in different abandonment times were concentrated very close to the axes centroid, which indicates that they maintain some independence of the correspondence with other variables. This is due to the fact that the index comes from the application of algorithms to the number of species found (Halffter et al., 2005), so searching for correspondence of the diversity index will not be of practical use.

\section{CONCLUSION}

It is the Poaceae and Asteraceae families that characterized the high Andean grassland ecosystem that maintained dominance in revegetalization areas, despite the secondary 
succession process with invasive species. The post-harvest abandonment time of L. meyenii and the seasonal period affected the behavior of composition, richness and dominance, which determined the variation of alpha and beta diversity. The visible recovery time of areas under revegetalization was evidenced after five years of abandonment, which indicates that the effect of land-use change was very severe in the loss of floral diversity; however, the linear canonical correspondence between floral composition and physical-chemical factors of the soil indicate the possibility of accelerating the process of replacement of temporary species by perennials, through the replacement of organic matter and possible correction of $\mathrm{pH}$.

\section{REFERENCES}

ACEVEDO, P.; DELIBES-MATEOS, M. Efectos de los cambios en los usos del suelo en las especies cinegéticas en el sur de España: repercusiones para la gestión. Ecosistemas, v. 22, n. 2, p. 33-39, 2013. https://doi.org/10.7818/ECOS.2013.22-2.06

ALI, S.; HAYAT, R.; BEGUM, F.; BOHANNAN, B. J. M.; INEBERT, L.; MEYER, K. Variation in soil physical, chemical and microbial parameters under different land uses in Bagrot valley, Gilgit, Pakistan. Journal of the Chemical Society of Pakistan, v. 39, n. $1,2017$.

ÁLVAREZ-LÓPEZTELLO, J.; RIVAS-MANZANO, I. V.; AGUILERA-GÓMEZ，L. I.; GONZÁLEZ-LEDESMA, M. Diversidad y estructura de un pastizal en El Cerrillo, Piedras Blancas, Estado de México, México. Revista Mexicana de Biodiversidad, v. 87, n. 3, p. 980-989, 2016. https://doi.org/10.1016/j.rmb.2016.06.006

ANDRADE, B. O.; KOCH, C.; BOLDRINI, I. I., VÉLEZ-MARTIN, E., HASENACK, H., HERMANN, J. M., OVERBECK, G. E. Grassland degradation and restoration: A conceptual framework of stages and thresholds illustrated by southern Brazilian grasslands. Natureza e Conservação, v. 13, n. 2, p. 95-104, 2015. https://doi.org/10.1016/j.ncon.2015.08.002

BARRAGÁN SOLÍS, A. La metáfora raíz como categoría de análisis en las representaciones de los cuidados paliativos. Cuicuilco, v. 18, n. 52, p. 133-153, 2011.

BRITTO, B. Actualización de las Ecorregiones Terrestres de Perú propuestas en el Libro Rojo de Plantas Endémicas del Perú. Gayana. Botánica, v. 74, n. 1, p. 15, 2017. https://doi.org/10.4067/s0717-66432017005000318

CABALLERO-VÁZQUEZ, J. A.; VEGA-CENDEJAS, M. E. Spatial patterns of diversity at local and regional scales in a tropical lagoon. Neotropical Ichthyology, v. 10, n. 1, p. 99-108, 2012. https://doi.org/10.1590/s1679-62252012000100010

CAMPO, A. M.; DUVAL, V. S. Diversidad y valor de importancia para la conservación de la vegetación natural. Parque Nacional Lihué Calel (Argentina). Anales de Geografía, v. 34, p. 25-42, 2014. https://doi.org/10.5209/rev_AGUC.2014.v34.n2.47071

CAO, C.; ZHANG, Y.; QIAN, W.; LIANG, C.; WANG, C.; TAO, S. Land-use changes influence soil bacterial communities in a meadow grassland in Northeast China. Solid Earth, v. 8, n. 5, p. 1119-1129, 2017. https://doi.org/10.5194/se-8-1119-2017

CÁRDENAS, C. El fuego y el pastoreo en el páramo húmedo de Chingaza (Colombia): efectos de la perturbación y respuestas de la vegetación. 2013. 135p. Tesis (Doctorals) Universitat Autònoma de Barcelona, Barcelona, 2013. 
CARO, C.; SÁNCHEZ, E.; QUINTEROS, Z.; CASTAÑEDA, L. Respuesta de los pastizales altoandinos a la perturbación generada por extracción mediante la actividad de "champeo" en los terrenos de la comunidad campesina Villa de Junín, Perú. Ecología Aplicada, v. 13, n. 2, p. 85-95, 2014.

CAYUELA, L. Análisis multivariante: volume 1. Tulipán: Área de Biodiversidad y Conservación, Universidad Rey Juan Carlos, 2011.

CONDORI, G. Influencia de la fragmentación en la diversidad de la flora silvestre y en los cambios de uso de suelo y cobertura vegetal en Huertas Huayrara, Puno. Ecosistemas, v. 21, n. 2 , p. 230-234, 2012.

CUESTA, F.; BECERRA, M. T. Biodiversidad y Cambio climático en los Andes: Importancia del monitoreo y el trabajo regional. REDESMA, v. 6, n. 1, p. 9-27, 2012.

CUTIMBO, M. C.; MARCOS, J.; ARO, A.; LISBETH, Z.; VIVANCO, T. Evaluación de pastos y capacidad de carga animal en el fundo "Carolina" de la Universidad Nacional del Altiplano - Puno Perú. Journal of High Andean Research, v. 18, p. 143-150, 2016.

ENRÍQUEZ, D.; DAME, M.; MERCADO, M.; BLANCAS, M. Diversidad y valor de importancia como herramientas para fundamentar un cambio de uso del suelo en Zacatecas, México. Revista de Ciencias Ambientales y Recursos Naturales, v. 2, n. 3, p. 18-27, 2016.

FATTAHI, B.; CHAHOUKIB, M. A. Z.; JAFARIB M.; AZARNIVANDB, H.; TAHMASEBIC, P. Relationships between Species Diversity and Biomass in Mountainous Habitats in Zagros Rangeland (Case Study: Baneh, Kurdistan, Iran). Journal of Rangeland Science, v. 7, n. 4, p. 316-330, 2017.

FIALLOS, L.; HERRERA, R. S.; VELÁZQUEZ, R. Flora diversity in the Ecuadorian Páramo grassland ecosystem. Cuban Journal of Agricultural Science, v. 49, n. 3, 2015.

GARTZIA, M.; PÉREZ-CABELlO, F.; BUENO, C. G.; ALADOS, C. L. Physiognomic and physiologic changes in mountain grasslands in response to environmental and anthropogenic factors. Applied Geography, v. 66, p. 1-11, 2016. https://doi.org/10.1016/j.apgeog.2015.11.007

GONZÁLEZ-PINTO, A.-L. Estructura y diversidad florística de la zona terrestre de un humedal urbano en Bogotá (Colombia). Revista Luna Azul, n. 45, p. 201-226, 2017. https://doi.org/10.17151/luaz.2017.45.11

HAGEN, J. B. Five Kingdoms, More or Less: Robert Whittaker and the Broad Classification of Organisms. BioScience, v. 62, n. $1, \quad$ p. 67-74, 2012. https://doi.org/10.1525/bio.2012.62.1.11

HALFFTER, G.; KOLEFF, P.; MELIC, A. Sobre diversidad biológica: el significado de las diversidades Alfa, Beta y Gamma. Zaragoza: SEA; CONABIO; DIVERSITAS \& CONACYT, 2005.

HALLOY, S. et al. Puntos y áreas flxibles (PAF) para inventarios rápidos del estado de la biodiversidad. Ecología en Bolivia, v. 46, n. 1, p. 46-56, 2011.

HAWKINS, B. A.; FIELD, R.; CORNELL, H. V.; CURRIE, D. J.; GUÉGAN, J.-F.; KAUFMAN, D. M.; TURNER, J. R. G. Energy, Water, And Broad-Scale Geographic Patterns Of Species Richness. Ecology, v. 84, n. 12, p. 3105-3117, 2003. https://dx.doi.org/10.1890/03-8006 
HINOJOSA, L.; NAPOLÉONE, C.; MOULERY, M.; LAMBIN, E. F. The "mountain effect" in the abandonment of grasslands: Insights from the French Southern Alps. Agriculture, Ecosystems and Environment, v. 221, p. 115-124, 2016. https://doi.org/10.1016/j.agee.2016.01.032

JURADO, P.; SAUCEDO, R.; MORALES, C.; MARTÍNEZ, M. Almacén y captura de carbono en pastizales y matorrales de Chihuahua. México: Instituto Nacional de Investigaciones Forestales, Agrícolas y Pecuarias, 2013.

KINDT, R.; COE, R. Tree diversity análisis: a manual and software for common statistical methods for ecological and biodiversity study. Nairobi: World Agroforestry center, 2011.

MCCAIN, C. M.; GRYTNES, J.-A. Elevational Gradients in Species Richness. In: Encyclopedia of Life Sciences (ELS). Chichester: John Wiley \& Sons, 2010. https://dx.doi.org/10.1002/9780470015902.a0022548

MIRAZADI, Z.; PILEHVAR, B.; ABRARI, V. Diversity indices or floristic quality index: Which one is more appropriate for comparison of forest integrity in different land uses? CECSA, v. 26, p. 1087, 2017. https://doi.org/https://doi.org/10.1007/s1053

MONTANERO, J. Manual abreviado de análisis estadístico multivariante. España: Universidad de Extremadura, 2018.

MORENO, C. E.; BARRAGÁN, F.; PINEDA, E.; PAVÓN, N. Reanalyzing alpha diversity: alternatives to understand and compare information about ecological communities. Revista Mexicana de Biodiversidad, v. 82, n. 1, p. 1249-1261, 2011. https://doi.org/10.1017/CBO9781107415324.004

MORENO, C. E. Métodos para medir la biodiversidad. M\&T - Manuales y Tesis SEA, v. 1, n. 84, 2001. https://doi.org/10.1371/journal.pone.0103709

MOTA, S.; RODRIGUEZ, J.; MESQUITA, N.; SILVA, E.; MAGALHÃES, M.; WILSON, G.; FERREIRA, J. Changes in species composition, vegetation structure, and life forms along an altitudinal gradient of rupestrian grasslands in south-eastern Brazil. Flora: Morphology, Distribution, Functional Ecology of Plants, v. 238, 2018. https://doi.org/10.1016/j.flora.2017.03.010

MUDONGO, E. I.; FYNN, R. W. S.; BONYONGO, M. C. Role of herbivore impact and subsequent timing and extent of recovery periods in rangelands. Rangeland Ecology and Management, v. 69, n. 5, p. 327-333, 2016. https://doi.org/10.1016/j.rama.2016.04.003

NIEMANDT, C.; GREVE, M. Fragmentation metric proxies provide insights into historical biodiversity loss in critically endangered grassland. Agriculture, Ecosystems and Environment, v. 235, p. 172-181, 2016. https://doi.org/10.1016/j.agee.2016.10.018

PERÚ. Ministerio del Ambiente. Estrategia nacional ante el cambio climático. Lima, 2014, p.88.

PLIENINGER, T.; HUNTSINGER, L. Complex Rangeland Systems: Integrated SocialEcological Approaches to Silvopastoralism. Rangeland Ecology and Management, v. 71, n. 5, p. 519-525, 2018. https://doi.org/10.1016/j.rama.2018.05.002

ROLANDO, J. L.; TURIN, C.; RAMÍREZ, D. A.; MARES, V.; MONERRIS, J.; QUIROZ, R. Key ecosystem services and ecological intensification of agriculture in the tropical highAndean Puna as affected by land-use and climate changes. Agriculture, Ecosystems and Environment, 2017. https://doi.org/10.1016/j.agee.2016.12.010 
ROSENZWEIG, M. L. Species Diversity in Space and Time. New York: Cambridge University Press, 1995. http://dx.doi.org/10.1017/CBO9780511623387

SCHMIDT, D. Servicios ecosistémicos de los pastizales naturales en Guichón, Paysandu, Uruguay. Birdlife International, v. 1, n. 29, 2018.

SEDLAR, Z.; ALLEGRO, A.; RADOVIĆ, A.; BRIGIĆ, A.; HRŠAK, V. Extreme land-cover and biodiversity change as an outcome of land abandonment on a Mediterranean island (eastern Adriatic). Plant Biosystems, v. 3504, p. 1-10, 2017. https://doi.org/10.1080/11263504.2017.1330774

SILVA MOTA, G.; LUZ, G. R.; MOTA, N. M.; SILVA COUTINHO, E.; DAS DORES MAGALHÃES VELOSO, M.; FERNANDES, G. W.; NUNES, Y. R. F. Changes in species composition, vegetation structure, and life forms along an altitudinal gradient of rupestrian grasslands in south-eastern Brazil. Flora: Morphology, Distribution, Functional Ecology of Plants, v. 238, p. 32-42, 2018. https://doi.org/10.1016/j.flora.2017.03.010

TANG, Z.; SUN, G.; ZHANG, N.; HE, J.; WU, N. Impacts of land-use and climate change on ecosystem service in Eastern Tibetan Plateau, China. Sustainability (Switzerland), v. 10, n. 2, p. 10-12, 2018. https://doi.org/10.3390/su10020467

UCHIDA, K.; KOYANAGI, T. F.; MATSUMURA, T.; KOYAMA, A. Patterns of plant diversity loss and species turnover resulting from land abandonment and intensification in semi-natural grasslands. Journal of Environmental Management, v. 218, p. 622 629, 2018. https://doi.org/10.1016/j.jenvman.2018.04.059

UNITED STATES. Department Of Agriculture - USDA. Soil survey manual. Soil Science Division Staff (Handbook N). USA, 2018.

WANG, Z.; DENG, X.; SONG, W.; LI, Z.; CHEN, J. What is the main cause of grassland degradation? A case study of grassland ecosystem service in the middle-south Inner $\begin{array}{llllll}\text { Mongolia. Catena, } & \text { v. 150, } & \text { p. }\end{array}$ https://doi.org/10.1016/j.catena.2016.11.014

WEHN, S.; ANDERS HOVSTAD, K.; JOHANSEN, L. The relationships between biodiversity and ecosystem services and the effects of grazing cessation in semi-natural grasslands. Web Ecology, v. 18, n. 1, p. 55-65, 2018. https://doi.org/10.5194/we-18-55-2018

WIESMAIR, M.; OTTE, A.; WALDHARDT, R. Relationships between plant diversity, vegetation cover, and site conditions: implications for grassland conservation in the Greater Caucasus. Biodiversity and Conservation, v. 26, n. 2, p. 273 -291, 2017. https://doi.org/10.1007/s10531-016-1240-5

WHITTAKER, R. H. Vegetation of the Siskiyou Mountains, Oregon and California. Ecological Monographs, v. 30, n. 3, p. 279-338, 1960. https://dx.doi.org/10.2307/1943563

YARANGA, R.; CUSTODIO, M.; CHANAMÉ, F.; PANTOJA, R. Diversidad florística de pastizales según formación vegetal en la subcuenca del río Shullcas, Junín, Perú. Scientia $\begin{array}{lllllll}\text { Agropecuaria, } & \text { v. } & 9, & \text { n. } & 4, & \text { p. } & 511-517,\end{array}$ https://doi.org/10.17268/sci.agropecu.2018.04.06

ZHOU, W.; GANG, C.; ZHOU, L.; CHEN, Y.; LI, J.; JU, W.; ODEH, I. Dynamic of grassland vegetation degradation and its quantitative assessment in the northwest china. Acta Oecologica, v. 55, p. 86-96, 2014. https://doi.org/10.1016/j.actao.2013.12.006 